\title{
FLUCTUATIONS IN THE DISTRIBUTION AND ABUNDANCE OF INTERTIDAL BARNACLES
}

\author{
By A. J. Southward and D. J. Crisp \\ From the Plymouth Laboratory and the Marine Biology Station \\ (University College of North Wales), Menai Bridge, Anglesey
}

(Text-fig. I)

It is well known that towards the limits of an animal's geographical range both its abundance and exact boundaries may fluctuate from time to time. These fluctuations can sometimes be correlated with environmental changes, and thus may help to assess the relative importance of the factors that control distribution. For example the distribution of the common intertidal barnacles Chthamalus stellatus (Poli) and Balanus balanoides (Linnaeus) underwent changes which were attributed to a general rise in temperature over several years (Southward \& Crisp, I954a). The abundance of these barnacles has fluctuated further since $195 \mathrm{I}-52$, and we are now able to analyse more closely the relation between the population changes and environmental variations.

\section{Geographical Distribution}

The present distribution of Chthamalus stellatus and Balanus balanoides illustrates very well Darwin's (1872) contention that where two allied species of different range have similar habits and habitats, the territory common to both is small compared with the areas occupied exclusively by either species. Thus, while on the eastern side of the Atlantic Chthamalus extends to the tropics and B. balanoides penetrates well inside the Arctic circle, the two occur side by side only in the British Isles and northern France. In the course of a general survey aimed at establishing on a quantitative basis the present distribution of some common intertidal animals, we have during the past few years determined carefully the distribution and boundaries of these barnacles in the area common to both. We give here (Fig. I) the present boundaries of these species in Europe, with our observations grouped into three classes, based on the numerical abundance of the animals: more detailed information has been, and will be, given elsewhere (Southward \& Crisp, I954b).

The advantage of demonstrating the limits of a species in terms of objective criteria of abundance rather than by mere records must be stressed. Scattered records of occurrence beyond the margin of measurable decline in population supply little useful information, even when reliable. In the past, too great a reliance has often been placed upon such records, and too often unreliable 
information (particularly misidentifications and mislabelled museum specimens) has been quoted by several authors in succession without attempt at verification. The number of authors referring to a record is no guide to its value.

Lack of quantitative information has been particularly confusing in the case of Chthamalus and B. balanoides, which are often mistaken for each other (cf. Darwin, I854). For example, there appears to be little factual basis for the reported occurrence of Chthamalus at Heligoland. The earliest records, as far as can be ascertained from the description (Frey \& Leuckart, I847), refer to

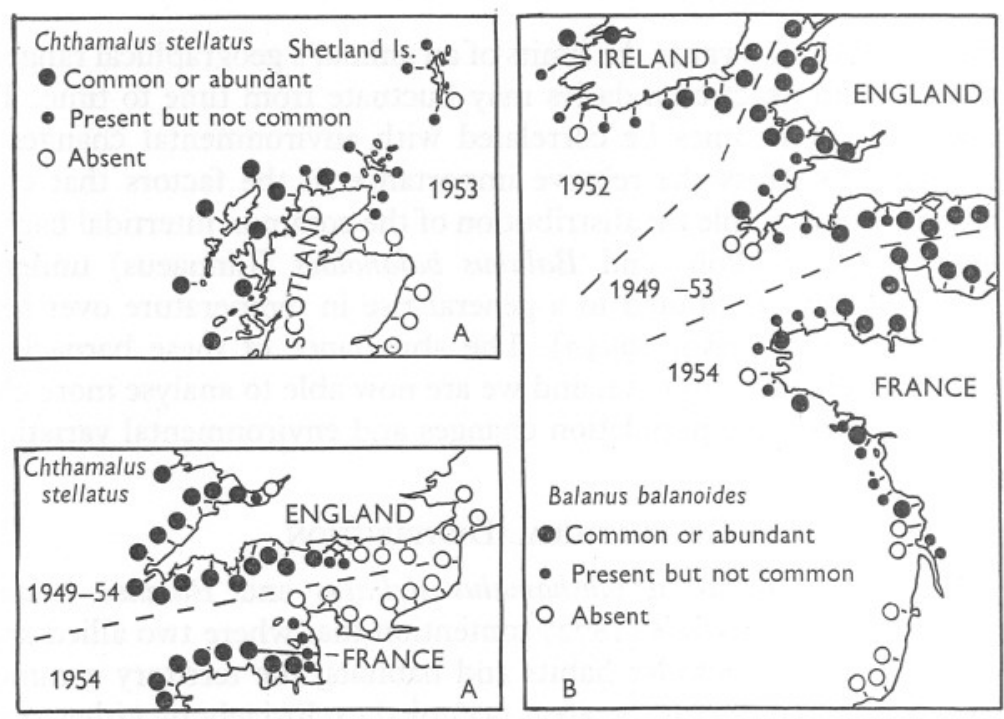

Fig. I A. The northern and eastern boundaries of $C$. stellatus in Europe. B: the known southern and western limits of Balanus balanoides in Europe. In each species, the dividing line between the present and common categories corresponds to a density of approximately 0.5 individuals per square centimetre.

B. balanoides, while Weltner's (1897) record is based on museum specimens on a mussel-shell, a most unlikely habitat for the barnacle at its limits. The supposed occurrence of $B$. balanoides in the Azores appears to be another example of confusion of these species; Barrois' (1888) account of the Crustacea and Nobre's fauna list (1924) are of dubious value since Chthamalus is not recorded at all, while Weltner (1900) gives neither locality nor authority in stating that $B$. balanoides is found in the Azores and Portugal. We have recently examined material collected in the Azores by Dr Chapman, to whom we are indebted for this kindness, and find all to be Chthamalus stellatus.

Even when comparing the present distribution of these barnacles with previous genuine records there is the disadvantage, already mentioned, that 
with notable exceptions the latter are non-quantitative. However, both Fischer-Piette (I936) and Moore \& Kitching (I939) give quantitative evidence from which, by comparison with our observations, the following changes in boundaries may be inferred:

(a) Between the 'thirties and I95I Chthamalus advanced eastwards in the English Channel from St Alban's Head and Swanage to the Isle of Wight. The most easterly record is now at Ventnor, while at St Catherine's Point it occurs at a density of $20-30 / \mathrm{m}^{2}$ at high-water mark. There does not seem to have been any corresponding extension along the coast of France.

(b) Between I936 and I953 Chthamalus spread southwards along the east coast of Scotland from Nybster to Wick, Lybster and Latheron.

(c) Between the 'thirties and I949-5I B. balanoides retreated from the south coast of Cornwall. The previous evidence is insufficient to show any changes in the position of the limits elsewhere.

\section{Relative Abundance of the Species}

By the end of I952, as reported in Southward \& Crisp (I954a), considerable evidence was available that in many parts of Britain there had been a change in the relative abundance of Chthamalus and B. balanoides since the 'thirties. It now appears that the increases of Chthamalus and the decreases of B. balanoides reached their extreme in 1951-52, and are at present undergoing reversal. The changes have been followed most closely in Devon and Cornwall, where they have been most obvious, but corroborative evidence is available from other places.

\section{Brixham, South Devon}

The densities of the two barnacles at Shoalstone Beach, Brixham, in I949 and I952, and each year since I952 are given in Table I (Appendix). The changes are most clearly brought out by comparing the percentage of $\mathrm{B}$. balanoides out of the total population of Chthamalus and B. balanoides:

$\begin{array}{lccccc} & \text { I949 } & \text { I952 } & \text { I953 } & \text { I954 } & \text { I955 } \\ \text { H.W.N. } & 38 & 4 & 5 & \text { I6 } & \text { I0 } \\ \text { M.T.L. } & 43 & \text { I4 } & 13 & 33 & 25 \\ \text { L.W.N. } & 93 & \text { I4 } & 32 & 43 & 50\end{array}$

The changes are most marked at L.W.N., where the rate of growth and the mortality are such that both species reach maturity in I year, and rarely survive more than 2 years. The evidence demonstrates that although the decline in B. balanoides was arrested, and then reversed, from 1953 onwards, the relative proportions of the two species are still different from those existing in I949. The failure of B. balanoides to recover its previous abundance, in spite of some good settlements since 1952, may be accounted for by the continued success of Chthamalus in maintaining a population between M.T. level and low water, the intertidal range most favoured by $B$. balanoides. 


\section{The Plymouth Area}

The results of the observations around Plymouth, at those stations originally chosen by Moore (1936), and at some other places, will be found in Table II (Appendix). In this area the decline in B. balanoides up to I95I was more marked, compared with the I934 survey, than that which took place at Brixham in 1949-52. The resurgence of the species in the Plymouth area has at some stations been correspondingly obvious, as the following figures (percentages B. balanoides out of total Chthamalus plus B. balanoides) for the estuary of the River Yealm show:

$\begin{array}{lcccc} & \text { I934* } & \text { I95I } & \text { I953 } & \text { I954 } \\ \text { H.W.N. } & \text { I6 } & <\text { I } & <\text { I } & \text { I } \\ \text { M.T.L. } & 87 & <\text { I } & 3 \text { I } & 40 \\ \text { L.W.N. } & \text { IOO } & <\text { I } & 9 & 33 \\ & \star & \text { From Moore (I936). }\end{array}$

However, the proportion of $B$. balanoides in the barnacle population of the Plymouth area has not yet reached the level that existed in 1934: at Brixham, where there are no data for the 'thirties, the present proportions of B. balanoides are now approaching those of the original survey in 1949.

At some stations in the Plymouth area, e.g. Tinside and Amory Bight, B. balanoides is still quite rare. In the Tamar Estuary Elminius modestus has remained the dominant barnacle, but at a few other sheltered sites where, for some reason, Elminius has always been less common, B. balanoides is now equal in number to, or outnumbers, Chthamalus at certain levels-e.g. the Breakwater jetty, and Baring Point in the River Yealm.

A most interesting point about the return of $B$. balanoides to Plymouth is that the species reappeared in some wave-beaten sites before other sheltered places. At Church Reef, Wembury, B. balanoides settled quite heavily, and survived, on the outermost reefs, as these figures (percentages B. balanoides out of total Chthamalus plus B. balanoides) show:

$\begin{array}{lcc} & \text { I95I } & \text { I954 } \\ \text { H.W.N. } & <\text { I } & 4 \\ \text { M.T.L. } & <\text { I } & 29 \\ \text { L.W.N. } & <\text { I } & 45\end{array}$

while at the shoreward end of the reef it was still as scarce as in 1950-5I. Similarly, in 1954, there was a greater density of B. balanoides at Amory Bight and on the south side of the Breakwater, than at Tinside on south-facing surfaces which are more sheltered from wave-action. Perhaps more rapid growth and higher mortality at wave-beaten sites causes a greater turnover of established individuals, and hence allows a change in the proportions of the two species to appear more quickly. Alternatively, during a period of increasing abundance larvae may come from elsewhere along the coast, and may therefore settle on the outer reefs first. It is possible that the Yealm Estuary 
provided a source of such larvae since it retained significant populations throughout the decline (cf. Table II, Baring Point) and was less heavily populated by Elminius than other local estuaries.

\section{North Devon and Cornwall}

On the northern coast of the Devon and Cornwall peninsula the present distribution of $B$. balanoides is irregular, and our observations are therefore not easy to interpret. An island of fairly high density exists at, and west of, St Ives nearly to Cape Cornwall. East of this B. balanoides is mainly restricted to parts of the coast in the neighbourhood of estuaries, for example at Padstow, Boscastle and Bude. Elsewhere it is often uncommon or rare.

Changes in the density of $B$. balanoides have been noticed only in those areas where the species is relatively sparse, and, in common with the changes observed at Plymouth and Brixham, they show a decrease up to about I95I and an increase since then. For example in I950-5I at Westward Ho!, Croyde Bay and Trevone, as reported in Southward \& Crisp (1954a), B. balanoides was practically absent, though it was known to have been present at these places in earlier years. Between I952 and I954 some settlements took place and at all three stations the species reappeared at low water in small numbers. As elsewhere, however, it is still less common than reported in the 'thirties by Moore \& Kitching (1939). At Millook Haven, for example, Moore reported the proportion of $12 \%$ B. balanoides to $88 \%$ Chthamalus, whereas in 1955 only $6 \%$ B. balanoides was found.

In the St Ives-Zennor region investigations were made in I950 and I955, and the population was found to be substantially the same. The density of B. balanoides was approximately half that recorded by Fischer-Piette (I936).

\section{South Cornwall}

B. balanoides was extremely rare to the west of Plymouth from I950 to I955. Only sporadic records of isolated individuals have therefore been obtained, and the evidence shows no trend.

\section{Scotland}

Since we reported the general increase in Chthamalus in the British Isles as a whole we have obtained more definite information on the changes in the Scottish area since the I930's. Our survey of the Scottish coast was undertaken in 1953, after the reversal of the previous trend, hence the maximum extent of the increase in Chthamalus is not known. Table III (Appendix) shows, however, that some increase in Chthamalus had occurred between I934 and I953, taking Moore \& Kitching's observations for the former period as a basis, and expressing ours as nearly as possible in the same form. For many stations, particularly those in Argyll and the Islands, no comparison 
is possible as the previous observations were insufficiently quantitative. For example, Kitching (1935) reports Chthamalus as 'plentiful' at two stations in Mull, one exposed and one sheltered, where we found it to constitute respectively 60 and $7 \%$ of the total barnacle population. At Millport, Cumbrae, the density of Chthamalus is given by Moore \& Kitching as $480 / \mathrm{m}^{2}$, which is not reconcilable with the figure of $7.5 \%$ by weight reported by the same authors for the whole intertidal zone.

In general, the main increase in numbers of Chthamalus in Scotland appears to have taken place on west- and south-facing shores.

\section{Irish Sea}

Observations on the coasts of the Irish Sea agree generally with those in south-west England. In the Isle of Man, the previous decrease in B. balanoides was reversed in 1952, and continued so during 1953-55, although no corresponding decline in Chthamalus was noted. At St John's Point, Co. Down, good settlements of $B$. balanoides were noticed on the outer, wave-beaten, reefs in 1953, although in greater shelter Chthamalus was still as dominant as it was in 1950 (percentages B. balanoides out of total Chthamalus plus B. balanoides):

$\begin{array}{lcc} & 1950 & 1953 \\ \text { H.W.N. } & <\mathrm{I} & 59 \\ \text { M.T.L. } & 38 & 95 \\ \text { L.W.N. } & - & 83\end{array}$

Along the Lancashire coast, at Blackpool and Rossall, Chthamalus has become less common than it was in 1950, but B. balanoides is not noticeably more abundant. Elminius, on the other hand, has increased considerably and is abundant even at high-water mark. This increase may well have contributed directly to the reduction in Chthamalus. At Blackpool in 1953 we found old individuals of the latter being overgrown by younger specimens of Elminius. Changes in the foreshore in this area as a result of storm damage and scour may also have had an adverse effect on a species which had only a precarious foothold in the locality.

\section{Relation to Environmental Changes}

In our previous paper (Southward \& Crisp, I954a) we suggested that the changes in the barnacle populations up to $195 \mathrm{I}-52$ were related to the higher sea and air temperatures then prevailing, the southern barnacle being favoured at the expense of the northern species. The recent increase of $B$. balanoides following a period of somewhat lower temperatures (see Tables IV-IX, Appendix) appears to support this view. However, the suggestion of Moore \& Kitching (1939) that the distribution of one of these barnacles, C. stellatus, was connected with the beneficial effect of water masses of Atlantic origin, has recently been revived by Powell (1954), with reference to its distribution in 
the north of Scotland. The most marked changes in the barnacle populations have occurred in the south-west of England, where Chthamalus is still much more abundant than it was in the 'thirties: yet in this area the proportion of western water, or water of mixed Atlantic and coastal origin, such as had been supposed to favour Chthamalus, appears to have continued at the reduced level of the 'thirties (e.g. see Corbin, 1950). The 'Atlantic Water' theory therefore becomes untenable when applied to account for the changes in distribution and abundance.

We shall now consider in more detail how temperature may influence the relative abundance of these two species. In Chthamalus, both at Brixham and the Isle of Man, fertilized egg masses, which released nauplii when ripe, were found in the mantle cavity during the breeding period-roughly from May to October-in all the years when observations were made. Therefore temperatures were always sufficiently high to allow the production of young. Nevertheless, summer temperature levels may have some influence on the reproduction. Like Elminius and other warm water forms, Chthamalus can produce more than one brood of nauplii (Crisp, I950). It is possible that, as has been demonstrated in Elminius (Crisp \& Davies, I955), the interval between broods is shorter at higher temperatures. Thus during a warm summer the number of broods and the larval output would increase directly. Further advantages to the planktonic larvae, the cyprid and the spat would probably result from a warm season, when development and growth would be more rapid, and temperatures closer to those normally experienced by the species at the centre of its geographical range.

Owing to the relatively long period during which Chthamalus produces successive broods in the south-west, the developmental stages in the plankton overlap with each other and with the growth of young spat. It is not therefore possible to separate these phases in the life history and to correlate them with temperature anomalies month by month. In 1949 and I950 (Table IV), however, there was better correlation between annual spatfall and monthly temperature for the months of July-October, than with the months of May and June. This suggests that the temperature requirements of embryonic development, which alone takes place in May and early June, are less exacting than the requirements of planktonic development and the growth of spat.

For the Isle of Man, the evidence is a little more decisive, for the settlement is confined to high water and is restricted to a later period of the year. (Settlement at high water, as distinct from settlement in lower parts of the intertidal zone, occurs later in the south-west also.) There is a good correlation between positive temperature anomalies for any or all months from September to December and good settlements of Chthamalus (Table V), rather than for the months from May to August. Taken together, the evidence from Brixham and the Isle of Man points to the need for warmth during the later larval stages and at the time of settlement, and possibly thereafter, rather than 
during gonad building and embryonic development. However, information over longer periods is desirable.

In the light of the above analysis we may examine mean sea and air temperatures for the months of July to December only, in order to attempt an explanation of the changes in the proportions of Chthamalus. At Torquay, from 1946 to the end of 1949, conditions were generally warm, with anomalies above the period mean (Table VI). From I950 to I954, there were 2 years, I950 and 1952, when the temperatures during these 5 months were consistently below the mean, but in the remaining years, the monthly means of sea or air temperature from July till December have been nearly always above the period means. During the same period at Plymouth (Table VII), except for 1950 and 1952, the temperatures were again consistently above the long period mean. Therefore, at these localities, and probably elsewhere in Britain, late summer and autumn temperatures, for 7 out of the 9 years 1946-54, were at a level that should have favoured good settlements of Chthamalus. Moreover, the 2 poor years, 1950 and 1952, were separated by a relatively better year. This temperature trend could therefore explain quite well the increase in the species and the continued maintenance of high densities in the south-west, even at low water. On this basis, it could be predicted that there will be no reduction in Chthamalus to its former proportions unless there is a succession of colder autumns.

Observations on the settlement of $B$. balanoides at Brixham show no close correlation with winter temperatures as a whole, nor with any particular month (Table VIII). However, over the period 1948-50, when the species was declining, temperatures were generally above the period mean. Since then, with certain exceptions, either sea or air temperatures (or both) have been below the period mean, and settlements, except in I95I, have correspondingly shown a marked increase. There would thus be some correlation of the recent more successful settlements of $B$. balanoides with lower winter temperatures, if some explanation could be given for the anomaly in $195 \mathrm{I}$. It must be remembered that at this time stocks of the species were probably low generally in the south-west, as they were known to be at Plymouth (Table II). Few young individuals were present at this time, for the spatfalls of 1948-50 appear to have failed to survive in any numbers. The old individuals had a very high rate of infection by the castrating parasite Hemioniscus (Southward \& Crisp, 1954a). If the generally colder conditions in the early part of I95I allowed the survival of the spatfall, small though it was, these younger individuals with, presumably, a lower infection rate of the parasite, would augment the spatfall the following year. A lag of this sort in the recovery of the species would not be surprising in view of its precarious position in the south-west.

At Plymouth the decline of $B$. balanoides during the warm period ending in I950 reached a much lower level than at Brixham, and it would be corres- 
pondingly more difficult for the species to return. Moreover, although since I95I temperatures below the long period average have occurred in January and February, in March and April, the months when settlement takes place, temperatures have been above the period mean.

The main part of this paper was prepared during the winter and spring of 1954-55. On the basis of the above discussion it was predicted that the persistent cold weather that occurred in the early part of 1955 might favour good settlements of $B$. balanoides in the south-west. The meteorological observations now available show that during the months of January to June 1955, apart from air temperatures for April, temperatures were consistently below the period means (Table $\mathrm{X}$ ). Sea temperatures were especially low in March and April, when the major (or only) settlement of B. balanoides takes place. It is therefore interesting to report that quite a good settlement of $B$. balanoides occurred in south Devon in the spring of 1955 . Comparatively heavy spatfalls $\left(\mathrm{I}-2 / \mathrm{cm}^{2}\right)$ were seen at Wembury, the Erme Estuary, and at Prawle Point in April and May. Good settlements were probably general along the whole of the south coast since Stubbings (private communication) reports exceptionally heavy and prolonged spatfalls of $B$. balanoides in the Portsmouth area. In the Menai Straits the settlement was heavier and more prolonged than had been experienced during the past 4 years.

Counts were made in the Plymouth and Brixham area in August 1955, when the spat had reached almost adult size, and these observations showed that increases in the relative proportions of the species had occurred at Brixham and in the Yealm Estuary, though no change was discernible at Plymouth, Tinside (Table X). At Wembury, although the relative proportions of $B$. balanoides and C. stellatus on the outer, wave-beaten, reefs were the same as in 1954, settlement had spread to the shoreward reefs from which the species had been completely absent for at least 5 years. Thus at three out of four localities, $B$. balanoides showed an increase in number or range during the cold spring of 1955 .

\section{INFLUENCE OF TEMPERATURE}

Darwin (1872) cautioned against attributing the distribution of an organism directly to temperature differences in the environment. He pointed out that competition between species would probably be the most exacting factor, but that this would be influenced by conditions of temperature or climate, which favoured one or other of the competitors.

There is little doubt that in south-west Britain, C. stellatus and B. balanoides are in direct competition over the greater part of the intertidal zone, for the total numbers supported by the environment have remained fairly constant in spite of changes in the proportions of each species. How, then, can temperature influence this competition?

We have already pointed out how warm summer temperatures may increase 
directly the fecundity and survival of Chthamalus, and support of this view is afforded by the heavy spatfalls in certain areas such as Loch Sween, Dundrum Bay, etc. (Southward \& Crisp, I954b). Increased fecundity will ultimately lead to increased intertidal cover by the species, and so deny rock space to its competitor. However, no similar beneficial effect of low winter temperature can increase the fecundity of $B$. balanoides, for the eggs are spawned by midwinter, before the sea and air temperatures reach their minima, and breeding can occur only once a year. Hence, then, low winter temperature can directly favour $B$. balanoides only by delaying embryonic development to a point where the larvae may benefit more from the spring phytoplankton, or, more dubiously, by some effect on the survival or vigour of the larvae or spat.

On the other hand, competition between the species for food is operating continuously and must be especially severe on young spat surrounded by cirral nets of older individuals. Moreover, barnacles will readily feed on newly hatched nauplii of their own or other species (unpublished observations). The rate of feeding of each species, in addition to its direct influence on its own growth and fecundity, will therefore influence competing species both by removal of food and by ingestion of their larvae.

It has been shown that the frequency of cirral beat in each species has an optimal temperature range; in $B$. balanoides it lies between $O$ and $18^{\circ} \mathrm{C}$, in Chthamalus between 5 and $30^{\circ} \mathrm{C}$ (Southward, 1955). Outside these ranges the species will not be able to feed efficiently. Results of frequency determinations show that after allowing for much individual variation, B. balanoides is the more efficient below about $15^{\circ} \mathrm{C}$, Chthamalus above (Southward, I955). Therefore the lower the temperature at which the spat of $B$. balanoides are growing, the less the competition to which they will be exposed. On the other hand, above $17^{\circ} \mathrm{C} \mathrm{B}$. balanoides shows reduced activity, while Chthamalus shows a rapidly increasing beat. High summer and autumn temperatures should therefore favour the survival of the spat of Chthamalus. On this basis the balance between the two species will depend on the temperature variation throughout the year, and their distribution limits would not necessarily correspond with temperature extremes.

Moore \& Kitching (1939) minimized the significance of competition as a limiting factor because the zones of adult Balanus and of adult Chthamalus were occasionally distinct. Our observations agree with most of theirs in that almost everywhere the zones interpenetrate, if only to a slight extent, with no space between them. The sharpness of separation of the two zones where it occurs could be an indication of extreme interspecific competition within each zone; it would also be enhanced by gregariousness on the part of the cyprid larvae (Knight-Jones, 1953), for Chthamalus has no appreciable effect in stimulating the setting of Balanus (Knight-Jones, 1955).

The view that competition, modified by temperature, is the main factor limiting each species however suggests possible explanations to problems 
which have been posed by previous authors. It explains the gradual restriction of Chthamalus, both in its northern and estuarine limits, to the upper zones where it suffers less competition from Balanus. The restriction of Chthamalus at its northern limits to very exposed headlands may not be due entirely to the suitability of exposed areas to Chthamalus; it may survive there because it is relatively better equipped to withstand severe exposure than is Balanus, and so benefits from lack of competition. The nature of the microhabitat, in which it is found under such conditions (viz. slightly sheltered cracks in the rock), suggests that the exposure is not optimal, but almost as severe as the species can endure. In more sheltered localities in most parts of Britain Balanus normally dominates completely, but it may be significant that wherever Chthamalus is found abundantly in shelter, other than in a narrow zone at high water, $B$. balanoides is scarce. For example, in harbours west of Plymouth, where Chthamalus occurs at all levels, B. balanoides is scarcely represented. In Loch Sween, B. balanoides is absent in the areas of abnormal abundance of Chthamalus (cf. Southward \& Crisp, I954b). In a similar way, the presence of Balanus balanoides in creeks and estuaries in south-west England, and its absence from the open coast, may be attributable to the adverse effect of estuarine conditions on Chthamalus stellatus.

We conclude that the distribution of these two species, with their similar habitat and habits, cannot be adequately explained by the action of the physical environment on either of them alone. We suggest, instead, a dynamic concept with the two competing species in a state of equilibrium. Even quite minor changes in the physical environment, favouring one or the other of the species, will, if sufficiently prolonged, cause the boundaries of distribution to alter.

We wish to express our thanks to Dr Eve C. Southward, Dr H. G. Stubbings, and $\mathrm{Mr}$ L. W. G. Jones for assistance in this work; to the Royal Society for financial assistance in the field surveys; to the D.S.I.R. for the grant of a Senior Research Award that enabled one of us (A. J. S.) to continue the investigations, and to I.C.I. (Paints Division) for access to information obtained during the period one of us (D. J. C.) was in their employment.

\section{SUMMARY}

Recent observations on the distribution and abundance of the commoner intertidal barnacles indicate that, following a decline up to I950-5I, the northern Balanus balanoides is now increasing in abundance. The influence of environmental variations, particularly temperature, is discussed.

It is suggested that the distribution of the two competing species B. balanoides and Chthamalus stellatus, and the fluctuations in their abundance, are best explained dynamically. The equilibrium existing between them is 
altered by changes in the environment, which give one species an advantage over the other. Temperature, which affects the cirral activity of the two species differently, has probably the most important influence on their relative abundance.

\section{REFERENCES}

AIR MINISTRy, 1936. Averages of Temperature for the British Isles for Periods ending I935. London.

- 1946-55. The Monthly Weather Report of the Meteorological Office. London.

Barrois, T., I888. Catalogue des Crustacés marins receuillis aux Açores. Lille.

Corbin, P. G., I950. The seasonal abundance of young fish. XI. The year I949. 7. Mar. biol. Ass. U.K., Vol. 30, pp. 271-5.

CRISP, D. J., I950. Breeding and distribution of Chthamalus stellatus. Nature, Lond., Vol. I66, p. 3II.

Crisp, D. J. \& Davies, P. A., I955. Observations in vivo on the breeding of Elminius modestus grown on glass slides. F. Mar. biol. Ass. U.K., Vol. 34, pp. $357-80$.

Darwin, C., I854. A Monograph on the Sub-class Cirripedia: Balanidae, Verrucidae, etc., 684 pp. London: Ray Soc.

- 1872. The Origin of Species by Means of Natural Selection. Sixth edition. London. [Chapters 3 and 6.]

FISCHER-PIETTE, E., I936. Études sur la biogéographie intercôtidale des deux rives de la Manche. F. Linn. Soc. (Zool.), Vol. 40, pp. I8I-272.

Frey, H. \& LeUCKART, R., I847. Beiträge zur Kenntniss wirbelloser Thiere. Braunschweig.

KITCHING, J. A., I935. An introduction to the ecology of intertidal rock surfaces on the coast of Argyll. Trans. roy. Soc. Edinb., Vol. 58, pp. 35I-74.

KNIGHT-JONES, E. W., I953. Laboratory experiments on gregariousness during setting in Balanus balanoides and other barnacles. F. exp. Biol., Vol. 30, pp. 58498.

- I955. The gregarious setting reaction of barnacles as a measure of systematic affinity. Nature, Lond., Vol. I74, p. 266.

Moore, H. B., 1936. The biology of Balanus balanoides. V. Distribution in the Plymouth area. F. Mar. biol. Ass. U.K., Vol. 20, pp. 70I-I6.

Moore, H. B. \& Kitching, J. A., I939. The biology of Chthamalus stellatus (Poli). F. Mar. biol. Ass. U.K., Vol. 23, pp. 52I-4I.

NoBre, A., I924. Contribuições para a Fauna dos Açores. An. Inst. Zool. Univ. Pôrto, Vol. I, pp. 4I-90.

Powell, H. T., I954. Occurrence of Chthamalus stellatus (Poli) in Fair Isle \& Shetland. Nature, Lond., Vol. I73, p. 688.

Southward, A. J., I953. Fluctuations in the sea and air temperatures at Port Erin during the past fifty years. Rep. Mar. biol. Sta. Pt Erin, No. 65, pp. 28-3r.

- 1955. On the behaviour of barnacles. I. The relation of cirral and other activities to temperature. F. Mar. biol. Ass. U.K., Vol. 34, pp. 403-22.

SouthwARD, A. J. \& CRISP, D. J., I954a. Recent changes in the distribution of the intertidal barnacles Chthamalus stellatus Poli and Balanus balanoides L. in the British Isles. F. Anim. Ecol., Vol. 23, pp. 163-77.

- $1954 b$. The distribution of certain intertidal animals around the Irish Coast. Proc. R. Irish Acad., Vol. 57 B, No. I, pp. I-29. 
SOUTHWARD, A. J. \& ORTON, J. H., I954. The effects of wave-action on the distribution and numbers of the commoner plants and animals living on the Plymouth breakwater. F. Mar. biol. Ass. U.K., Vol. 33, pp. I-19.

WeltNeR, W., 1897. Beiträge zur Meeresfauna von Helgoland. IX. Die Cirripedien Helgolands. Wiss. Meeresuntersuch. Abt. Helgoland, N.F., Bd. 2, pp. 437-47.

— 1900. Die Cirripedien der Arktis. Fauna arct., Fena, Bd. I, pp. 287-312.

\section{APPENDIX}

\section{Table I. The Distribution and Abundance of Certain Barnacles at SHOALSTONE BEACH, BRIXHAM, I949-55}

(The levels are only approximate. The density is given in numbers per square centimetre, based on counts at several different places at each level. Some of the counts made within 5 months of the larval settlement show the numbers of adults and spat separately.)

\begin{tabular}{|c|c|c|c|c|c|c|c|c|c|c|}
\hline & \multicolumn{2}{|c|}{ March 1949} & \multicolumn{2}{|c|}{ February 1952} & \multicolumn{2}{|c|}{ May 1953} & \multicolumn{2}{|c|}{ April I954 } & \multicolumn{2}{|c|}{ January 1955} \\
\hline & בัँ & 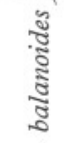 & 胥 & 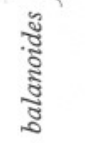 & ב్ & 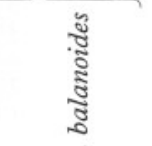 & 胥 & 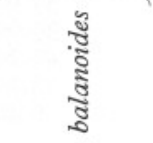 & 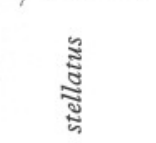 & 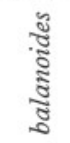 \\
\hline Level & $\dot{0}$ & $\dot{\theta}$ & $\dot{0}$ & $\infty$ & $\dot{0}$ & $\infty \dot{0}$ & $\dot{0}$ & $\infty$ & $\dot{0}$ & $\dot{\theta}$ \\
\hline $\begin{array}{l}\text { H.W.N. } \\
\text { M.T.L. }\end{array}$ & $\begin{array}{l}2 \cdot 76 \\
2 \cdot 64 \\
0 \cdot 15\end{array}$ & $\begin{array}{l}1 \cdot 69 \\
1 \cdot 98 \\
2 \cdot 00\end{array}$ & $\begin{array}{l}5.49 \\
2 \cdot 80 \\
2 \cdot 10\end{array}$ & $\begin{array}{l}0.25 \\
0.45 \\
0.35\end{array}$ & $\begin{array}{l}9.5 \\
6.8 \\
4.8\end{array}$ & $\begin{array}{l}0.55+0.40 \\
I .05+0.80 \\
2.25+\mathrm{I} .60\end{array}$ & $\begin{array}{l}4 \cdot 55+7 \cdot 75 \\
2 \cdot 20+4 \cdot 15 \\
I \cdot 60+2 \cdot 70\end{array}$ & $\begin{array}{l}0.85+0.70 \\
\mathrm{I} \cdot 10+\mathrm{I} \cdot 95 \\
\mathrm{I} \cdot 20+2 \cdot 70\end{array}$ & $\begin{array}{l}3.02+0.28 \\
3.14+0.74 \\
0.88+0.32\end{array}$ & $\begin{array}{l}0.34 \\
\text { I.06 } \\
0.87\end{array}$ \\
\hline
\end{tabular}

\section{Table II. The Distribution and Abundance of Certain Barnacles in Plymouth AREA, I95I-54}

(To be compared also with tables in Moore, I935. The numbers are given as the average per square metre, based on 2-5 counts of areas of $25-100 \mathrm{~cm}^{2}$ at each level; the levels at Tinside were referred to the nearest bench mark of the Ordnance Survey, and those on the Breakwater obtained from Southward \& Orton (I954), but at the other stations the levels were estimated by reference to the predicted height of the tide at the time; counts of Chthamalus made later in the year than September give adults and young specimens separately.)

(a) Amory Bight, between Rame Head and Penlee Point

September I95I

C. stellatus

Level in metres, relative to o.D.

$\begin{array}{rr}3 \cdot 9 & 450 \\ 3 \cdot 3 & 2,200 \\ 2 \cdot 7 & 67,600 \\ 2 \cdot 3 & - \\ 2 \cdot 1 & 75,200 \\ \mathrm{I} \cdot 5 & 73,600 \\ 0.9 & 78,200 \\ 0.6 & - \\ 0 \cdot 2 & 44,400 \\ -0 \cdot 2 & - \\ -0 \cdot 4 & 23,400 \\ -\mathrm{I} \cdot 0 & \mathrm{I} 5,500 \\ -\mathrm{I} \cdot 6 & 9,600\end{array}$

December 1954

\begin{tabular}{|c|c|}
\hline C. stellatus & B. balanoide \\
\hline Adults Spat & \\
\hline- & - \\
\hline 2,200 & 0 \\
\hline $12,400+1,000$ & $\circ$ \\
\hline $41, \overline{600}+r, 400$ & $\overline{100}$ \\
\hline $40,000+8,800$ & 1,600 \\
\hline $4 \mathrm{I}, 600+56,000$ & 800 \\
\hline $28,800+32,000$ & 200 \\
\hline $12,000+4,000$ & 0 \\
\hline
\end{tabular}




\section{(TABLE II-continued)}

(b) Plymouth Breakwater, vertical pile of jetty on north side

\begin{tabular}{|c|c|c|c|c|c|c|}
\hline \multirow[b]{2}{*}{$\begin{array}{l}\text { Level } \\
\text { M.T.L. }\end{array}$} & \multicolumn{3}{|c|}{ September I95 I } & \multicolumn{3}{|c|}{ October 1954} \\
\hline & $\begin{array}{c}\text { C. stellatus } \\
44,800\end{array}$ & $\begin{array}{c}\text { B. balanoides } \\
\mathrm{r}, 000\end{array}$ & $\begin{array}{l}\text { E. modestus } \\
\mathrm{I}, \mathrm{IOO}\end{array}$ & $\begin{array}{l}\text { C. stellatus } \\
16,000\end{array}$ & $\begin{array}{c}\text { B. balanoides } \\
16,000\end{array}$ & E. modestus \\
\hline
\end{tabular}

(c) Plymouth Breakwater, south side, Traverse B of Southward \& Orton, I954

September I95 I

October 1954

\begin{tabular}{|c|c|c|c|c|}
\hline \multirow[t]{2}{*}{ Level (m) } & \multirow[t]{2}{*}{$\overparen{C . \text { stellatus }}$} & \multirow[t]{2}{*}{ B. balanoides } & C. stellatus & \multirow[t]{2}{*}{ B. balanoides } \\
\hline & & & Adults Spat & \\
\hline $3 \cdot 0$ & 28 & 0 & $570 \quad 0$ & 0 \\
\hline 2.5 & I 2,200 & 0 & $33,600+8,000$ & 0 \\
\hline $2 \cdot 0$ & 9,500 & o & $35,200+12,400$ & o \\
\hline $\mathrm{I} \cdot 5$ & 46,400 & o & $48,000+17,600$ & 0 \\
\hline$I \cdot 0$ & 37,600 & 0 & $37,600+38,000$ & 2 \\
\hline 0.5 & 30,600 & 0 & $38,400+24,000$ & 80 \\
\hline O.D. & 40,200 & 200 & $24,600+36,000$ & I, IOO \\
\hline-0.5 & 33,200 & 0 & $20,800+22,800$ & 2,800 \\
\hline$-I \cdot 0$ & 9,400 & 2 & II $, 600+8,400$ & 500 \\
\hline
\end{tabular}

(d) Tinside, below the laboratory

September I95I

C. $B$.

Level $(\mathrm{m}) \quad$ stellatus balanoides

\begin{tabular}{|c|c|}
\hline $2 \cdot 28$ & 500 \\
\hline I. 88 & \\
\hline $\begin{array}{l}\mathrm{I} \cdot 67 \\
\mathrm{I} \cdot 38\end{array}$ & 28,840 \\
\hline $\begin{array}{l}1.06 \\
\mathrm{I} .06\end{array}$ & 32,400 \\
\hline $\begin{array}{l}0.88 \\
0.45\end{array}$ & 30,800 \\
\hline 0.38 & \\
\hline $\begin{array}{l}-0.16 \\
-0.62\end{array}$ & 24,000 \\
\hline $\begin{array}{l}-0.02 \\
-0.77\end{array}$ & I9,600 \\
\hline$-\mathrm{I} \cdot \mathrm{I} 2$ & \\
\hline $\begin{array}{l}-\mathrm{I} \cdot 38 \\
\text { Shaded }\end{array}$ & $\mathrm{I}, \mathrm{I} 50$ \\
\hline $\begin{array}{l}\mathrm{rraces} \text { at } \\
-\mathrm{I} \cdot 3\end{array}$ & - \\
\hline
\end{tabular}

400
October 1953

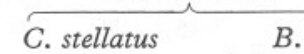

$\overbrace{\text { Adults Spat }}^{\text {C. stellatus }}$

$800 \quad \therefore \quad$

$26,0 \overline{0}+6,0 \overline{0}$

$24,800+32,000$

$27,200+32,000$

$21,200+24,000 \quad \overline{60}$

二
December 1954

\begin{tabular}{|c|c|}
\hline C. stellatus & B. \\
\hline Adults Spat & \\
\hline $\begin{array}{r}500 \\
4,800+\end{array}$ & $\begin{array}{l}\circ \\
\circ\end{array}$ \\
\hline $24,000+8,000$ & \\
\hline $34,800+16,000$ & \\
\hline $24, \overline{0} \overline{0}+27,2 \overline{-}$ & To \\
\hline $\begin{array}{l}34,800+21,600 \\
24,000+16,800\end{array}$ & 200 \\
\hline $24,000+16,800$ & $\stackrel{\circ}{-}$ \\
\hline $\begin{array}{r}2,800+12,400 \\
500+1,600\end{array}$ & $\begin{array}{l}\circ \\
\circ\end{array}$ \\
\hline
\end{tabular}

$B$.

balanoides

$\frac{0}{\circ}$
$\frac{0}{\circ}$
$\frac{60}{6}$
$\frac{-}{0}$

(e) Henn Point, Tamar Estury

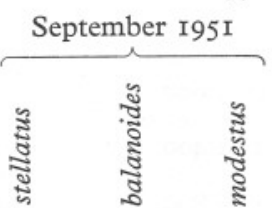

Level $(\mathrm{m})$

$\begin{array}{ll}I \cdot I & 550 \\ 0.4 & 400\end{array}$

0.2

O.D.

$-0.2$

$-0.7$

$-I \cdot 9$
October 1953

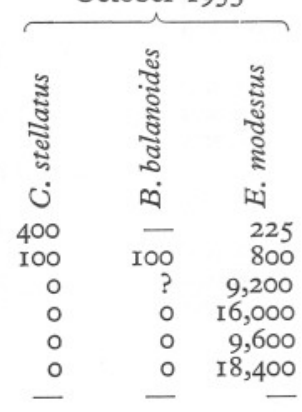

December 1954

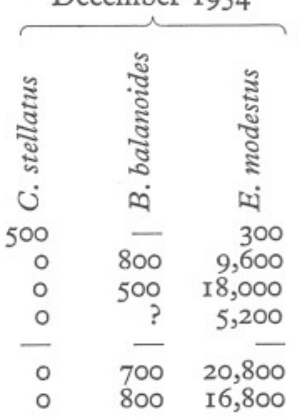




\section{(TABLE II-continued)}

(f) Misery Point-Cellar Beach, Yealm Estuary

\begin{tabular}{|c|c|c|c|c|c|c|}
\hline \multirow[b]{3}{*}{ Level (m) } & \multicolumn{2}{|c|}{ September I95I } & \multicolumn{2}{|c|}{ October I953 } & \multicolumn{2}{|c|}{ December I954 } \\
\hline & \multirow{2}{*}{$\begin{array}{c}\text { C. } \\
\text { stellatus }\end{array}$} & \multirow{2}{*}{$\begin{array}{c}B . \\
\text { balanoides }\end{array}$} & C. stellatus & \multirow{2}{*}{$\begin{array}{c}B . \\
\text { balanoides }\end{array}$} & C. stellatus & \multirow{2}{*}{$\underset{\text { balanoide }}{B .}$} \\
\hline & & & Adults Spat & & Adults Spat & \\
\hline 3.0 & - & - & $\mathrm{I}, 200 \quad 0$ & 0 & - $\quad-$ & - \\
\hline $2 \cdot 7$ & 4,500 & $\circ$ & - $\quad-$ & - & $I, 600$ & 0 \\
\hline $2 \cdot 4$ & & - & $20,000+2,000$ & 0 & - $\quad-$ & - \\
\hline $2 \cdot I$ & 46,800 & 0 & - - & 一 & $80,000+2,000$ & 1,200 \\
\hline$I \cdot 5$ & $4 \mathrm{I}, 200$ & 100 & $48,000+$ I I, 200 & 0 & $68,000+24,000$ & 6,000 \\
\hline$I \cdot 2$ & - & - & $60,000+13,600$ & 0 & $26 \overline{0}+27$ & - \\
\hline 0.9 & 73,600 & 0 & - & - & $26,400+27,200$ & 4,800 \\
\hline $\begin{array}{l}0.6 \\
0.3\end{array}$ & $30, \overline{-}$ & $\overline{0}$ & $16,000+18,000$ & 5,500 & - $\quad$ - & - \\
\hline o.D. & - & - & $16,000+32,000$ & 7,00 & $12,000+32,000$ & 8,200 \\
\hline-0.3 & $2 \mathrm{I}, 200$ & $\circ$ & - - & - & $24,000+16,000$ & 5,600 \\
\hline-0.6 & - & 一 & $29,600+40,000$ & I,600 & 3,200 & 1,600 \\
\hline-0.9 & 766 & 0 & 4,000 & 400 & - & - \\
\hline \multirow[t]{3}{*}{$-I \cdot 5$} & 0 & ० & - & - & 400 & 800 \\
\hline & \multicolumn{2}{|c|}{ September I95I } & $\begin{array}{l}\text { Baring Point, Ye } \\
\text { October }\end{array}$ & $\operatorname{lm}$ Estuar & \multicolumn{2}{|c|}{ December I954 } \\
\hline & C. & $B$. & C. & $B$. & C. stellatus & D. \\
\hline Level & & oalanotaes & stellatus & & Adults Spat & \\
\hline H.W.N. & 3,700 & 200 & ? & $?$ & $8,000+2,000$ & 400 \\
\hline M.T.L. & 2,500 & $\mathrm{I}, 000$ & ? & 2,600 & $2,000+4,000$ & I3,600 \\
\hline
\end{tabular}

\section{TABle III. AbundancE ${ }^{\star}$ of $C$. STELlatus IN Scotland}

Place

Nybster, Caithness

Dunnet Head, Caithness

Skullomie, Sutherland

Geodha Chobhair, Sutherland

Seana Chamas, Ross

Elgol, Skye

Easdale, Seil

Loch Melfort, Argyll

Ardnoe Point, Argyll

Southend, Kintyre
In $1934-36$ (from

Kitching, I935; Moore \& Kitching, 1939)

Rare -2 found in 15 min No change, but $5 / \mathrm{m}^{2}$ at Wick Rare -6 seen in Io min $0.2 \%$ (mean of observations $0.6 \%$

$6.4 \%$

$0.6 \%$

I0 $\%$

Scarce

Scarce

Rather sparse

Absent on both sides of headland) $0.8 \%$ (but much commoner at Farr Bay, to the east) $29 \%$

$3 \%$ (on shores to north and south, between 20 and $40 \%$ ) Not visited; corresponding area on Sleat, $56 \%$ I $1.4 \%$ $30 \%$ $700 / \mathrm{m}^{2}$ $7 \%$

* As numbers found at H.W.N. in a certain time, or numbers per unit area of rock at H.W., or as percentage of total barnacle population over whole intertidal zone. 
Table IV. Settlement of C. Stellatus at Shoalstone Beach, Brixham, in ReLation to Temperatures at ToRQUAy Nearby

\begin{tabular}{|c|c|c|c|c|c|}
\hline \multirow{3}{*}{$\begin{array}{l}\text { Numbers per sq. cm. at end of main } \\
\text { settlement (July-October) }\end{array}$} & \multirow{3}{*}{$\begin{array}{l}\text { H.W.N. } \\
\text { M.T.L. } \\
\text { L.W.N. }\end{array}$} & \multicolumn{2}{|c|}{ I949 } & \multicolumn{2}{|c|}{ I950 } \\
\hline & & \multicolumn{2}{|c|}{$\begin{array}{l}\text { I2 } \\
\text { I4 } \\
28\end{array}$} & \multicolumn{2}{|c|}{$\begin{array}{r}5 \\
5 \\
\text { II }\end{array}$} \\
\hline & & Air & Sea & Air & Sea \\
\hline $\begin{array}{l}\text { Monthly anomalies of mean tempera- } \\
\text { ture }\end{array}$ & $\begin{array}{l}\text { July } \\
\text { Aug. } \\
\text { Sept. } \\
\text { Oct. }\end{array}$ & $\begin{array}{l}+\mathrm{I} \cdot \mathrm{I} \\
+0.5 \\
+2.0 \\
+\mathrm{I} .6\end{array}$ & $\begin{array}{l}+2.2 \\
+0.8 \\
+2.2 \\
+2.1\end{array}$ & $\begin{array}{l}-0.3 \\
-0.7 \\
-0.5 \\
-0.6\end{array}$ & $\begin{array}{l}0 \\
-0.1 \\
-0.5 \\
-0.6\end{array}$ \\
\hline
\end{tabular}

Note. Anomalies of sea temperature are relative to the means for the period $1946-54$; anomalies of air temperature are relative to the means for the period 1906-35. In this and subsequent tables the anomalies are based on sea and air temperatures supplied by the following authorities: Borough Meteorologist, Torquay; Director, Marine Biological Station, Port Erin; Port Health Officer, Plymouth. Additional values of temperature, including the means of air temperature for the period I906-35, were obtained from the following: Air Ministry, 1936; Air Ministry, I946-55: Southward, r953.

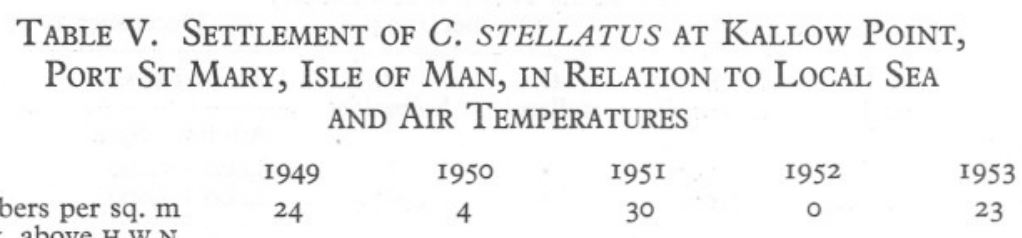

Numbers per sq. $\mathrm{m}$
at $\mathrm{I}$ ft. above H.W.N.

24

4

30

23

the following spring

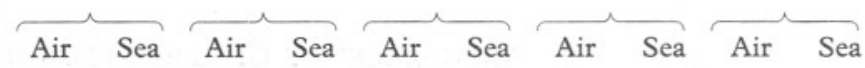

Monthly Sept, $+\mathrm{I} \cdot 9+\mathrm{I} \cdot \mathrm{I}-0.9 \quad 0 \quad+0.3-0.2-0.9-0.9+0.4+0.5$

anomalies of Oct. $+\mathrm{I} \cdot 3+\mathrm{I} \cdot 0-0.3-0.4+0.6+0 . \mathrm{I}-2.0-\mathrm{I} \cdot 2+0.4+0.6$

mean tem- Nov. $+0.3+0.5-\mathrm{I} .5-0.9+0.9+0.7-2.7-\mathrm{I} .0+2.4+0.7$

perature Dec. $+0.6+0.2-3 \cdot 0-\mathrm{I} \cdot 2+0.6+\mathrm{I} \cdot \mathrm{O}-\mathrm{I} \cdot 3-\mathrm{I} \cdot 3+2 \cdot 0+\mathrm{I} \cdot 2$

Note. The anomalies are relative to the means for the period $1947-53$. 
Table Vi. Anomalies of Mean Air, and Mean Sea $†$ Temperatures at Torquay

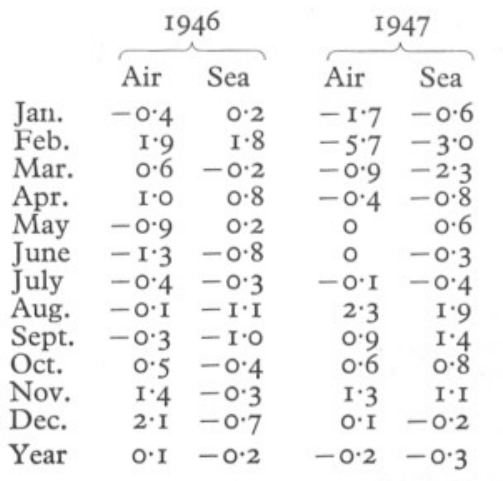

$\begin{array}{cr}\text { Air } & \text { Sea } \\ I \cdot I & 0.9 \\ O \cdot I & 0.9 \\ 2 \cdot I & 0.7 \\ 0.5 & 0.3 \\ 0 . I & 0.8 \\ -0.1 & -0.5 \\ -0.5 & -0.2 \\ -0.9 & -0.1 \\ -0.3 & 0 \\ 0 & -0.1 \\ I \cdot 9 & 0.1 \\ I \cdot I & I \cdot I \\ 0.4 & 0.3\end{array}$

$\begin{array}{cc}\text { Air } & \text { Sea } \\ 0.8 & 0.6 \\ \text { I.2 } & \text { I.I } \\ 0 & 0.3 \\ \mathrm{I} \cdot 3 & 0.7 \\ \text { O.I } & 0.5 \\ -0 \cdot \mathrm{I} & \mathrm{I} \cdot 2 \\ \mathrm{I} \cdot \mathrm{I} & 2 \cdot 2 \\ 0.5 & 0.8 \\ 2 \cdot 0 & 2 \cdot 2 \\ \mathrm{I} \cdot 6 & 2 \cdot \mathrm{I} \\ 0 & 0.2 \\ 0.5 & 0.5 \\ 0.8 & \mathrm{I} \cdot 0\end{array}$

* Relative to the means for the period 1906-35.
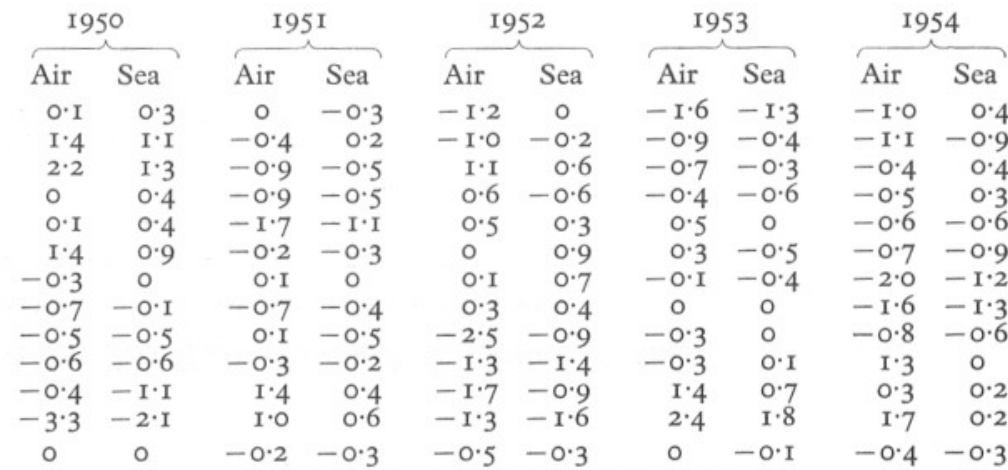

† Relative to the means for the period 1946-54.

Table ViI. Anomalies of Mean Air Temperature, ${ }^{*}$ Plymouth Hoe, and Mean Sea Temperature, $†$ Plymouth Tinside

\begin{tabular}{|c|c|c|c|c|}
\hline & \multicolumn{2}{|c|}{1946} & \multicolumn{2}{|c|}{ I947 } \\
\hline & Air & Sea & Air & Sea \\
\hline Jan. & -0.3 & 0.6 & $-I \cdot 9$ & -0.6 \\
\hline Feb. & $\mathrm{I} \cdot 8$ & $I \cdot O$ & $-5 \cdot 7$ & $-2 \cdot 7$ \\
\hline Mar. & 0 & 0 & -0.7 & $-\mathrm{I} \cdot 9$ \\
\hline Apr. & I.9 & 0.9 & 0.7 & $0 \cdot I$ \\
\hline May & 0 & 0.3 & 0.8 & -0.2 \\
\hline June & $-I \cdot I$ & 0.3 & 0.5 & -0.2 \\
\hline July & -0.2 & 0.4 & 0.3 & -0.4 \\
\hline Aug. & I'2 & -0.5 & 3.7 & $\mathrm{I} \cdot 5$ \\
\hline Sept. & 0 & -0.2 & $1 \cdot 4$ & $I \cdot 6$ \\
\hline Oct. & 0.8 & 0 & 0.9 & $I \cdot 3$ \\
\hline Nov. & $2 \cdot 0$ & 0.3 & I. 7 & I. 5 \\
\hline Dec. & $-\mathrm{I} \cdot 6$ & -0.2 & 0.2 & I.O \\
\hline Year & $0 . \mathrm{I}$ & 0.3 & 0.1 & 0 \\
\hline
\end{tabular}

$\begin{array}{lc}\text { Air } & \text { Sea } \\ \mathrm{I} \cdot 0 & 0.7 \\ 0 & 0.5 \\ 3 \cdot \mathrm{I} & 0 . \mathrm{I} \\ \mathrm{I} \cdot 4 & 0.4 \\ \mathrm{I} \cdot 2 & 0.9 \\ 0 & 0.2 \\ 0 & -0.6 \\ 0 & 0 \\ 0.3 & -0.2 \\ 0.4 & 0.3 \\ 2 \cdot 2 & 0.6 \\ \mathrm{I} \cdot \mathrm{I} & 0.8 \\ 0.9 & 0.3\end{array}$

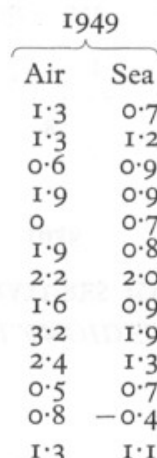

* Relative to the means for the period $1906-35$.

\begin{tabular}{|c|c|}
\hline \multicolumn{2}{|c|}{1950} \\
\hline Air & Sea \\
\hline$-0 . I$ & 0.6 \\
\hline $\mathrm{I} \cdot 6$ & I. 3 \\
\hline $2 \cdot 4$ & $I \cdot I$ \\
\hline 0.6 & 0.6 \\
\hline I. 2 & 0.8 \\
\hline$I \cdot 9$ & I.3 \\
\hline-0.1 & 0.4 \\
\hline-0.3 & 0.3 \\
\hline-0.4 & $O \cdot I$ \\
\hline-0.2 & $-0 . I$ \\
\hline-0.3 & -0.3 \\
\hline-3.0 & -0.6 \\
\hline
\end{tabular}
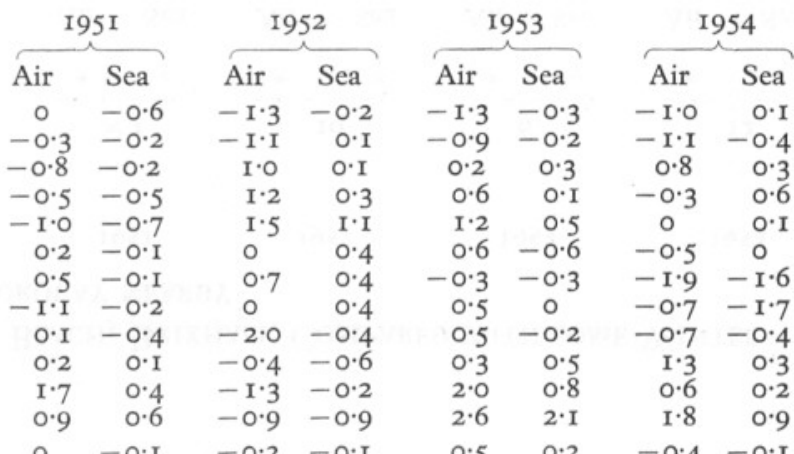

$\dagger$ Relative to the means for the period $1893-1948$. 
Table ViII. The Settlements of B. Balanoides at Shoalstone Beach, Brixham, Compared With Some Winter TeMPERATURES EXPERIENCED at TORQUAY NEARBY

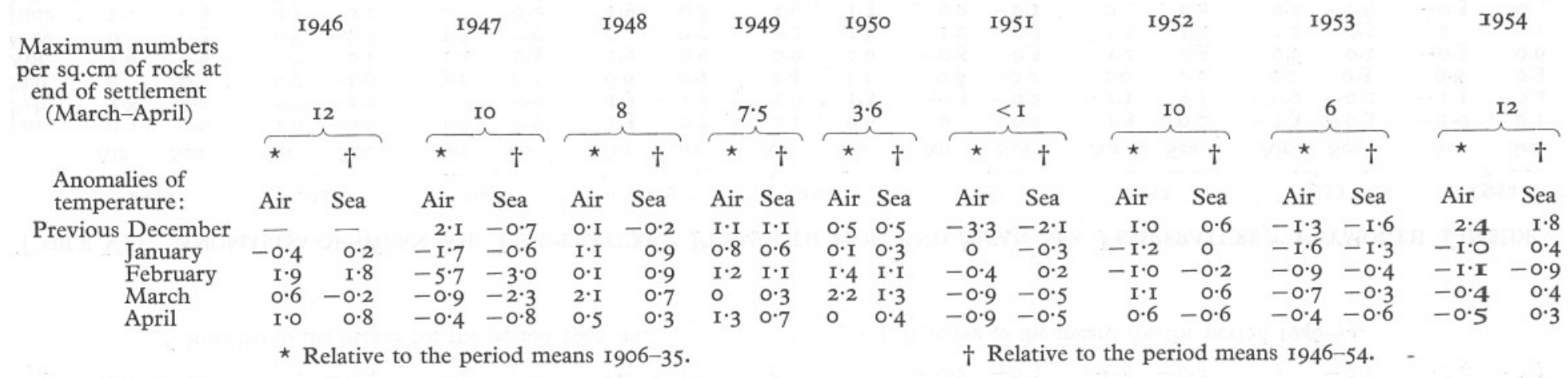

Table IX. Anomalies of Mean Annual Air Temperature* at Douglas, and Mean Annual Sea Temperature† at Port Erin, Isle of Man

$$
\begin{array}{ccccccccc} 
& \text { I946 } & \text { I947 } & \text { I948 } & \text { I949 } & \text { I950 } & \text { I95 I } & \text { I952 } & \text { I953 } \\
\text { Air } & 0 & -0.2 & 0.2 & 0.4 & -0.2 & -0.3 & -0.4 & 0.6 \\
\text { Sea } & 0.3 & -0.7 & 0 & 0.7 & 0.3 & -0.2 & -0.2 & 0.2
\end{array}
$$

* Relative to the grand mean for $1906-35$.

+ Relative to the grand mean for $1903-5 \mathrm{I}$. 
Table X. The Abundance of B. Balanoides at Certain Localities in South Devon, August i955, as Numbers per Square Centimetre of Rock, Showing the Relation of the Spring Settlement of Spat to SEA AND AIr Temperatures

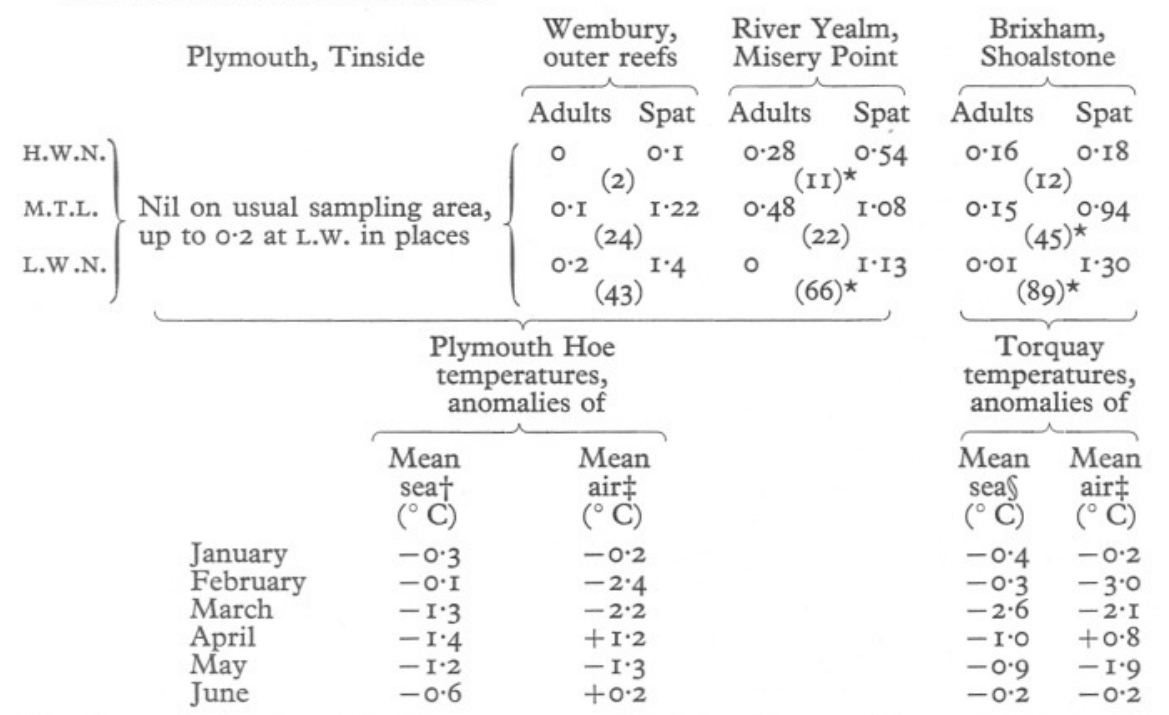

The figures in brackets show the percentage of B. balanoides out of the total B. balanoides and Chthamalus stellatus populations.

* Indicates an increase in this percentage compared with I954.

+ Relative to the grand means for the period I900-55.

\$ Relative to the grand means for the period 1906-35.

$\$$ Relative to the grand means for the period $1947-54$. 